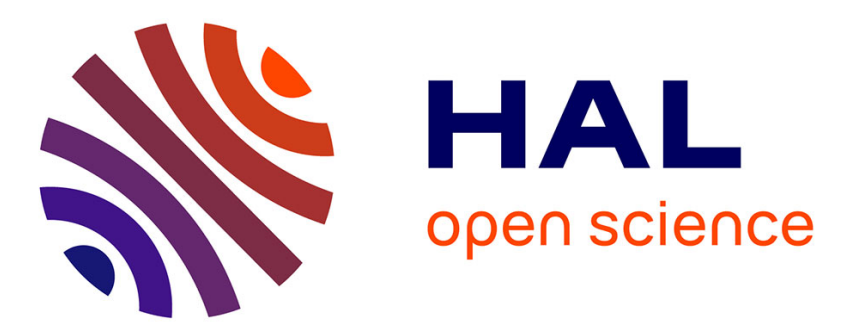

\title{
The Ability in Antiquity of Some Agrarian Societies to Avoid the Malthusian Trap and Develop
}

Clement Allan Tisdell, Serge Svizzero

\section{To cite this version:}

Clement Allan Tisdell, Serge Svizzero. The Ability in Antiquity of Some Agrarian Societies to Avoid the Malthusian Trap and Develop. Forum for Social Economics, 2017, pp.1-26. 10.1080/07360932.2017.1356344. hal-02145482

\section{HAL Id: hal-02145482 \\ https://hal.univ-reunion.fr/hal-02145482}

Submitted on 3 Jun 2019

HAL is a multi-disciplinary open access archive for the deposit and dissemination of scientific research documents, whether they are published or not. The documents may come from teaching and research institutions in France or abroad, or from public or private research centers.
L'archive ouverte pluridisciplinaire HAL, est destinée au dépôt et à la diffusion de documents scientifiques de niveau recherche, publiés ou non, émanant des établissements d'enseignement et de recherche français ou étrangers, des laboratoires publics ou privés. 


\title{
The Ability in Antiquity of Some Agrarian Societies to Avoid the Malthusian Trap and Develop
}

\author{
Clement Tisdell ${ }^{1}$ and Serge Svizzero ${ }^{2}$ \\ ${ }^{1}$ School of Economics, The University of Queensland, St Lucia \\ 4072, Australia; ${ }^{2}$ Faculté de Droit et d'Economie, Université de la \\ Réunion, Réunion, France
}

\begin{abstract}
This article presents a simple economic theory (and associated evidence) to explain how some early agriculturally based preindustrial societies developed despite most of their population being subject to Malthusian dynamics. Their development depended on a dominant class limiting its membership and extracting an economic surplus which it could use (among other things) to accumulate capital and advance knowledge thereby adding to this surplus. The evolution of urban centers facilitated this development process. Extraction of the agricultural surplus prevented increased population from dissipating this surplus and curtailing development. Examples are given of early economically extractive and non-inclusive societies which were long lasting. Their persistence is at odds with the views of some contemporary development economists about the development prospects of these types of societies.
\end{abstract}

Keywords: institutional economics, Malthusian trap, Neolithic development, population dynamics, social inequality and development

JEL codes: O1, P4, N00

\section{INTRODUCTION}

It is generally recognized that two major economic revolutions resulted in substantial increases in the global population of human beings. Both had profound consequences for economic development and brought about major social changes. 
These were the evolution of agriculture in the Neolithic period which subsequently was able to support significant urban settlements and much later, the Industrial Revolution (Childe, 1936, 1950; Deevey, 1960; Livi-Bacci, 2007, p. 24).

Although Childe's contributions (which are given particular attention in this article) are not recent, it is hard to improve on Childe's initial formulation of the constellation of constituent components that make up the Neolithic revolution. As stated by Zeder (2009, p. 12), "While the empirical details that Childe provides have not [arguably] stood the test of time, his discussion of the basic nature of the Neolithic and its key distinguishing features remains the most thoughtful and complete consideration of this pivotal turning point in human history, encompassing the full range of economic, social, and ideological transformations found in more recent treatments of Neolithic emergence in the Near East". Nevertheless, several of Childe's most important hypotheses have been supported by more recent archaeological evidence. These include the hypothesis that the evolution of agriculture is associated with a substantial increase in human population (see, for example, Hassan, 1981, pp. 221-229 and references provided by him). Childe also stressed the pivotal role which urban centers played in the economic development of some ancient economies. Their importance was also stressed by Adam Smith in his division of the stages of economic development (Meek, Raphael, \& Stein, 1978; Svizzero \& Tisdell, 2016). A detailed account of the emergence of urban centers in several ancient societies and their demographic importance is given in Hassan (1981, pp. 235-257). Both of these hypotheses of Childe are followed up in this article, and it is therefore appropriate that his work be considered.

The development of settlements reliant on agriculture is seen by many writers as heralding the commencement of civilization and as being the basis for subsequent intellectual and cultural advances by humankind. In addition, in many preindustrial societies, significant economic innovations occurred and major public works were completed. It is unlikely that this type of economic progress would have been achieved (in the absence of substantial urban centers) if the whole of the population was subject to Malthus' theory of population dynamics. His theory suggests that, during the agricultural stage of development, resource surpluses beyond the maintenance of subsistence consumption were channeled primarily into population growth. How then can development in preindustrial agrarian societies be explained? The purpose of this article is to present a simple theory of how this was possible. In doing so, it relies heavily on changes in the social structure of societies.

Several influential economists (for example, Clark, 2007) have recently provided support for Malthus' theory of population dynamics. Clark $(2007$, p. 1) states that before 1800 , there was no upward trend in income per person and that because of the Malthusian trap, short-term gains in income as a result of technological advances were inevitably lost due to population growth. While this seems true for the masses, because of the mechanisms outlined in this article, it did not prevent 
continuing technological progress and capital accumulation (features of economic development) in some preindustrial societies. Furthermore, Ashraf and Galor (2011) paint a dismal picture of preindustrial societies and provide statistics which indicate that the average per capita level of income in these societies remained at subsistence level, despite the occurrence of some technological progress. Galor (2005) and Ashraf and Galor (2011) elaborate on the well-known view that the Industrial Revolution represents a great divide in the process of economic development. Not only did it eventually result in demographic transition but it was also associated with increased equality of income.

Galor (2005) contends that inequality of income was a significant impediment to economic development in agrarian societies. Moreover, Galor, Moav, and Vollrath (2009) express this view in relation to more recent historical events. Galor (2005) argues that the historical evidence does not support the thesis that past income inequality significantly promoted capital accumulation and economic growth. $\mathrm{He}$ considers that substantial economic inequality has always been correlated with extreme concentration of political power, and that this power has always been used to widen income gaps through rent-seeking and rent-keeping forces that can demonstrably retard economic growth. However, we argue that this thesis does not hold in some significant preindustrial contexts.

Although the thesis that the bulk of the population in agrarian societies lived at subsistence level has not gone unquestioned (see for example Maddison, 2007), in developing the following theory, we accept that the bulk of the population in early agrarian societies was subject to Malthusian-like population dynamics and lived approximately at subsistence level.

We argue that some such societies were able to achieve significant investment in capital works and the advancement of knowledge because a large proportion of their economic surplus was appropriated by a relatively small dominant class and the number of members of this class was constrained. Note that our theory does not assume that the dominant class had fewer offspring than 'commoners' but that in many cases, the entitlements of their offspring were restricted. The appropriation of the economic surplus produced by the dominated class (the 'commoners') limited the growth in the level of their population. Otherwise, the growth in the level of the population of the dominated class would have completely dissipated the potential available economic surplus, given the Malthusian theory of population growth (cf. Brenner, 1976).

In other words, our theory explains how some societies in antiquity were able to develop despite the Malthusian trap. Another potential (and divergent) explanation of this early economic development is to imagine the existence of a Boserupian process. Boserup's theory assumes that population pressure stimulates sufficient innovation to ensure adequate food supply. Livi-Bacci (2007, p. 83) points out that Boserup's approach (Boserup, 1965, 1981) overturns the Malthusian model as 
population becomes not a variable dependent on development but one which itself determines development. We do not find this theory to be convincing as a general theory (as is also argued by Hassan, 1981, Chapter 10), and retain Malthus' theory as being broadly applicable in early agricultural societies but argue that their economic growth depended (among other things) on the numbers in the dominant class being constrained. Incidentally, Cohen (1977) developed a similar theory to Boserup, but as detailed by Hassan (1981, p. 219), archaeological evidence does not support his theory. Although Lee (1986) developed a general demographic theory in which the models of Boserup and Malthus are special cases, this theory does not take account (as we do) of factors (mostly social ones) determining membership of the ruling class, and the consequences of this membership. Furthermore, it should be noted that the article is not about determining the veracity of the model of Boserup vs. that of Malthus but instead shows how (economic) development was able to occur in antiquity even if Malthus' theory applied.

The development of a society as well as its economic development is a multidimensional concept. While increased income per capita and reduced income inequality are often used as indicators of economic development, other indicators can also be considered. These include the ability of a society to produce a growing range of artifacts, its increasing ability to control nature to its advantage, to extend its means of transport and communication, and develop new forms of artistic and cultural expression. In addition, its ability to build and supervise the construction of infrastructure (such as roads, irrigation schemes) may also be taken into account. Increased trade (exchange), regional and occupational specialization, greater division of labor, and improved methods of coordinating the activities and social cohesion of larger sized political units are other possible indicators of societal development. Even in the absence of a significant increase in per capita income, and no decline in income inequality, many of the above-mentioned other indicators of (economic) development can remain positive. Indeed, in some cases, maintaining inequality is a prerequisite for these indicators to be positive.

This article is set out as follows. First, the economic theory of the extraction of the economic surplus and its consequences for population growth and development are outlined. Then it is shown how, given this extraction, the dominant class could gain from capital accumulation and the support for knowledge creation. Examples are provided. Factors that limited the size (membership) of the dominant class are subsequently considered. The theory is then placed in a wider historical context by considering the pivotal role for socioeconomic evolution of the development of urban centers. Their growth was made possible by extracting the economic surplus. 


\section{DEMOGRAPHIC AND ECONOMIC CONSEQUENCES OF THE EXTRACTION OF THE ECONOMIC SURPLUS BY THE DOMINANT CLASS}

Extraction of the economic surplus in agrarian societies by the dominant class provided the means for capital accumulation (including additions to human capital), resources for their defense, and commodities for consumption by the elite. The long-run fate of such societies was influenced by the balance achieved between the potential uses of the economic surplus. Defense expenditure and extravagant consumption by the elite reduced the surplus available for capital accumulation. Some agrarian societies may have been in the unfortunate position of having to allocate most of their economic surplus to defense in order to survive, or try to do so. In any case, it is clear that the dominant class had a strong economic interest in appropriating the economic surplus ${ }^{1}$ generated by the dominated. ${ }^{2}$

The simple type of economic relationships involved can be illustrated by Figure $1 .^{3}$ In this model, the level of the agricultural output, $Y$, of a society is assumed to depend on the level of the population of the dominated class, $X$. Given the existing technology and capital, the marginal productivity of the dominated class is indicated by line $\mathrm{ADE}$ and line $\mathrm{ABC}$ as its average productivity. Assume that the subsistence level of income is OS per head. Then in the absence of any appropriation of the surplus ${ }^{4}$ by the dominating class, the equilibrium population of the dominated will be $X_{3}$ given Malthus' theory. The economic surplus is entirely dissipated in this case. Suppose, however, that the dominant class imposes a levy of ST per head on the dominated. The equilibrium level of population of the dominated class is now $X_{1}$ (this is much smaller than if an egalitarian system of distributing output existed) and an economic surplus equivalent to the area of the hatched rectangle SDVT is appropriated. Total agricultural output is equal to the area of rectangle OLVT. Note

\footnotetext{
${ }^{1}$ The surplus of agricultural output is the type of economic surplus focused on in this article. The pool of surplus (underemployed) productive labor was an additional resource which was sometimes drawn on (for instance, as corvée labor) by ancient rulers to increase their wealth. It is not included in our analyses.

${ }^{2}$ The assumption of a society consisting of just two classes (the dominant and the dominated) is a theoretical simplification. In reality, ancient agrarian societies mostly displayed differences in the economic and social status of members of the ruling class.

${ }^{3}$ This is a similar diagram to that often used to illustrate one of the misallocation consequences of open access to natural resources (see, for example, Tisdell, 2005, p. 136, Figure 6.1).

${ }^{4}$ Although the economic surplus in this article is measured by the size of the agricultural surplus, it may also be measured by the size of the food surplus, as is done by Lee and Tuljapurkar (2008), Puleston and Tuljapurkar (2008), and Lee, Puleston, and Tuljapurkar (2009) in their models of food-dependent population growth in prehistoric times. Lee and Tuljapurkar (2008) point out that 'food is a major determinant of health, mortality and fertility and thus the growth rates of preindustrial agricultural populations'. It is also clear that food is needed to support those producing items other than food as well as the non-production. All human activities depend on individuals having an adequate amount of food. Modeling by Lee and Tuljapurkar (2008) differs from that in this article because it does not consider factors influencing membership of the ruling class.
} 


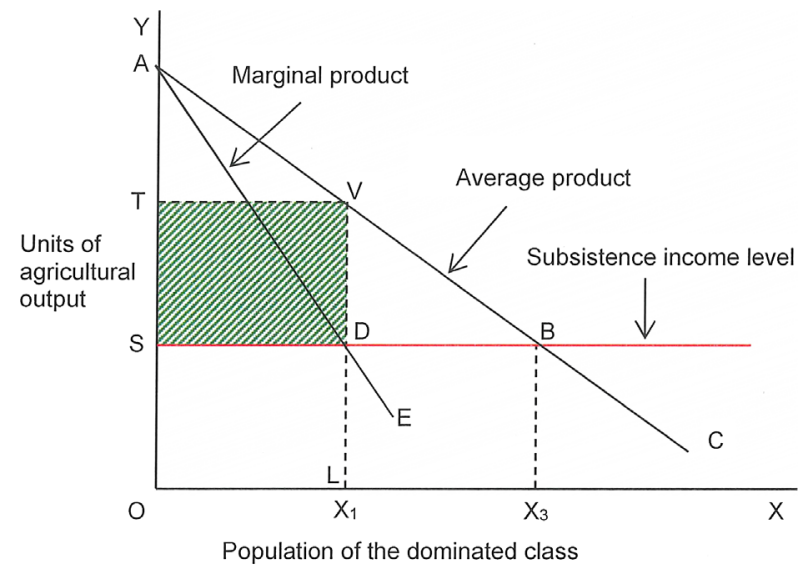

Figure 1: An illustration that the dominant class by appropriating the economic surplus generated by the dominated class prevents the dissipation of this surplus. In this illustration, an agricultural levy of ST is imposed on each member of the dominated class, the population of this class is restricted to $X_{1}$ and the rulers appropriate the equivalent of the hatched rectangle for their own use. In the absence of any appropriation of the agricultural surplus, the population of the masses increases to $X_{2}$, if Malthus' theory of population growth applies. Then there is no economic surplus and prospects for economic development are grim. The society is caught in a poverty trap.

the levy of ST per head imposed on the dominated maximizes the amount of surplus collected by the rulers. A higher levy would reduce the amount collected, and result in a counterproductive extraction rate. Also a lower levy fails to maximize the amount of the surplus obtained by the rulers.

It should be pointed out that there are in fact several methods by which the dominant class can extract an economic surplus from the dominated. The above method is just one. The dominant class may, for example, make use of corvée labor, slaves, or serfs and may directly possess a disproportionate amount of agricultural resources, especially land. Nevertheless, the general implications of the above model apply to these situations.

Note that we do not specify the dynamics by which the dominated population adjusts its level of population in relation to the availability of income. Stability, however, requires that not all members of this population be equally vulnerable to a reduction in income of this population when all are already at subsistence level; otherwise, all could perish (Tisdell, 2013, pp. 141-150). In practice, members of this population could have differences in their ability to access income when it becomes scarcer or may vary in their fitness, that is their ability to temporarily survive food 
deprivation. In their dynamic model, Ashraf and Galor (2011) make variations in the numbers of surviving children, the adjustment variable. However, adjustment mechanisms to the population (if it decreases) could also include the death of the less fit (such as the elderly) and those who have been excluded by 'stronger' persons from adequate access to food in times of shortage.

The development of agrarian societies depends on the use which the dominating class makes of the appropriated economic surplus. After meeting its military requirements and satisfying its consumption, the remaining sum can be invested by the ruling class to increase the amount of the surplus the ruling class can appropriate in the future. This is assuming that its investments are productive.

Milanovic, Lindert, and Williamson (2007) provide some empirical evidence of the magnitude of the extraction ratio in some preindustrial societies. They infer the extent of economic inequality for 14 preindustrial societies, stretching from the Roman Empire 14 AD, to the Byzantium in 1000, to England in 1688, to Nueva España around 1790, to China in 1880, and to British India in 1947. One of their results $(2007$, p. 28$)$ is that the extraction ratio-how much potential inequality was converted into actual inequality — was significantly higher in preindustrial times than now. The ratio shows how powerful and extortionary the elite were, its institutions and its policies. However, their paper focuses on measuring inequality in preindustrial societies, and does not explore the social structure underpinning inequality nor its determinants. In recent years, a growing number of mostly European scholars have been busy collecting new archival data in order to determine long-term trends in economic inequality in preindustrial times. For example, Alfani (2015) found that increasing economic inequality in Northwestern Italy during the period 1300-1800 showed little or no association with the presence or absence of economic development during that time. It tended to increase anyway partly as a result of structural and institutional changes. He concludes (2015, p. 1092) that the Kuznets income inequality curve (Kuznets, 1955) may no longer be "a general tool for interpreting the link between economic development and inequality, with its implicit promises, but a description of what happened during a relatively short phase, the Industrial Revolution". Alfani's results are not inconsistent with our analysis.

In ancient socially stratified agriculturally based societies, the evidence about the level of extraction of the economic surplus by the ruling class is more indirect, but nonetheless for several cultures is quite compelling. For example, Callender (1994, p. 90) reports that Mycenaean (Greek) civilization (c 1900-1200 BC) was highly stratified. The Wanax (the supreme ruler) of its palace-based societies stood at the apex of their social pyramids. He owned three times the amount of land of the next group in the social pyramids (the lawagetas). He also had the largest amount of slaves, was able to extract rents from 'commoners' for the use of land, and obtain tributes from the lawagetas. As well, he played the major role in the central direction of these economies, in the redistribution of the agricultural surplus, and in trade 
(Callender, 1994). Consequently, economic inequality was very marked. This is also evident for the ancient Egyptian kingdoms and nascent states in Mesopotamia (Hassan, 1981).

Our analysis is based on the simple assumption that the emergence of a suitable type of economic surplus is necessary for the occurrence of economic inequality. This view is present in the relevant literature; see for example, Diamond (1997, 2013) and Cunliffe (2015). The aggregate amount of the economic surplus determined the theoretical potential for economic inequality (Milanovic, Lindert, \& Williamson, 2011). Actual economic inequality depends on the extraction ratio (the proportion of the surplus extracted), the absolute size of the economic surplus, and the numbers in the dominant or privileged class, as well as economic inequality within this class. For simplicity, we have assumed in our analysis that all the economic surplus can be extracted by the dominant class. However, it is clear that an extraction ratio of $100 \%$ is unlikely to be achieved and that the actual extraction ratio is likely to vary depending on administrative methods for collecting the surplus, and other influences. It is also clear from our analysis that attempts to extract too high a proportion of the economic surplus can be counterproductive. Indeed, Callender (1994, Chapter 21) attributes the collapse of Mycenaean society to excessive economic exploitation of the masses by their rulers, which resulted in rebellion and the burning of their palaces by the deprived. However, none of these considerations invalidate our general hypothesis about why some ancient agrarian economies were able to develop and persist despite Malthusian population dynamics being applicable to them.

\section{THE INCENTIVE OF THE DOMINANT CLASS TO UNDERTAKE INVESTMENT}

The scope available to the dominant class to increase its economic surplus is illustrated by the example in Figure 2. As before, OS is the subsistence level of income of the dominated class and the line marked ADE shows its initial marginal productivity relationship. As a result of investing some of its economic surplus, the dominant class is assumed to increase the marginal productivity of the dominated group. This may result in the marginal productivity relationship moving up to the line HJK. The maximum economic surplus available to the dominant class now increases by an amount equivalent to the dotted trapezium ADJH. Originally, this surplus was equivalent to the hatched area shown. If the maximum amount of economic surplus is appropriated by the dominant class, the population of the dominated group increases from $X_{1}$ to $X_{2}$ following investment from the economic surplus. However, the level of income of the dominated remains at the subsistence level. They gain no economic advantage. The only group that has an economic gain 


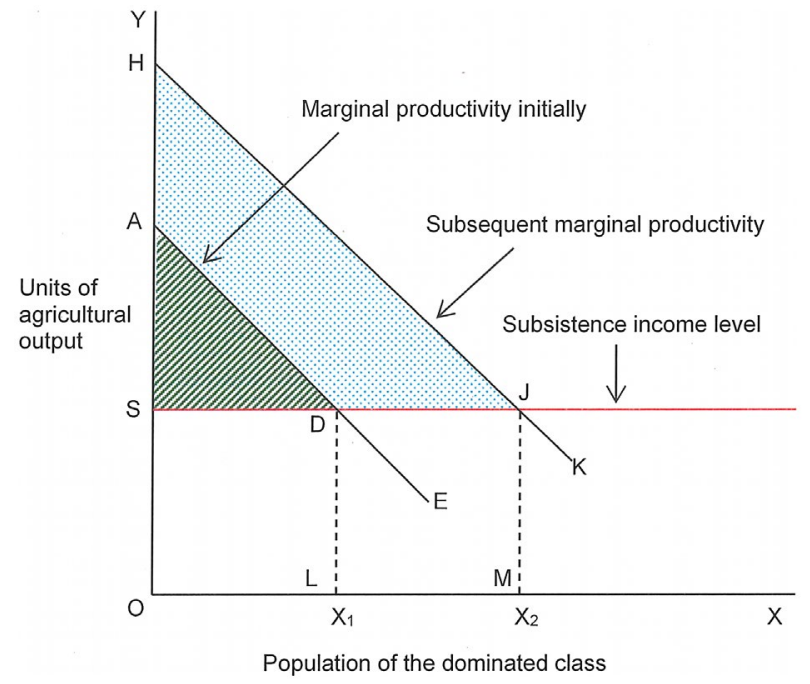

Figure 2: A case in which investment of at least some of the economic surplus adds to the economic surplus and results in an increased population of the dominated group. This figure shows that the ruling class can have an economic interest in raising the productivity of its subservient laborers. In this case, if the rulers are able to raise the marginal productivity of these laborers from the relationship ADE to HJK, the potentially available economic surplus available to the rulers increases by an amount equivalent to the area of quadrilateral ADJH.

is the dominant class. Total agricultural output rises from an area equivalent to the area of quadrilateral OLDA to that equivalent to the area of quadrilateral OMJH.

The dominant class is unlikely to know the exact amount it should levy on the dominated to appropriate the maximum amount of the economic surplus. Nevertheless, even if it only approximates this levy, the same general consequences follow.

Note that the above theory seems to be at odds with Childe's (1936, pp. 230-231) assertion that the rulers who emerged after the urban revolution had few incentives to encourage invention. He bases this thesis on the view that these rulers "now commanded almost unlimited reserves of labour recruited from subjects fired with superstitious faith and captives taken in war; they had no need to bother about labour saving inventions" (Childe, 1936, p. 231). However, as the above theory demonstrates, these rulers could gain substantially by increasing the productivity of labor. Nevertheless, in some cases, they may not have chosen to do this or they may have been too constrained by necessary expenditure on defense to have funds left to do this. 
It might be contended that the example given in Figure 2 does not adequately take account of Childe's viewpoint because the result of the productivity increase depicted is to increase the demand for labor. However, suppose that the marginal productivity curve of labor after a productivity-enhancing event is much steeper than illustrated but starts at point $\mathrm{H}$ and passes through a point near the left-hand side of $\mathrm{D}$. The total demand for labor declines in this case but the economic surplus rises. If all the ruling class wants to do is to raise its economic surplus, it would not be concerned by whether this increases or decreases the employment and the size of the population of the dominated class.

\section{MECHANISMS LIMITING THE SIZE OF THE RULING CLASS}

We emphasize that our theory does not depend on the ruling class having fewer offspring than 'commoners'. Its main purpose is to point out that other things being held equal, the speedier the increase in the membership of this class and also the greater the access of its members to the appropriated economic surplus, the faster the dissipation of the economic surplus appropriated by the ruling class. Consequently, the disposable economic surplus of this class declines with the passage of time if membership of this class and access to its resources are not limited. This may, however, be offset to some extent by rising agricultural productivity which increases the available economic surplus. If the initial appropriate surplus is large and productivity growth is significant, dissipation could take some time, and the relevant civilization could still experience economic development for a considerable period of time. Nevertheless, in some ancient economies, mechanisms were in place which limited membership of the ruling class and ensured inequality in the access of its members to its resources.

In other words, our theory depends on the size of the membership of the ruling class not being determined by the population principle of Malthus but on its being limited socially and otherwise. If the membership of the dominant class were to increase at a faster rate than its appropriated amount of the economic surplus, the amount of its available discretionary surplus (that is the amount left over after meeting its own basic needs) diminishes. In the long term, all of its discretionary economic surplus could disappear in this case. The time needed for this to happen depends on the rate of increase of the membership of the dominant class relative to the rate of change in the amount of the economic surplus it appropriates. The amount of the economic surplus appropriated by the ruling class depends on the extraction ratio and the aggregate amount of the surplus. In turn, the amount of the latter depends on factors identified above, including technological progress. The long-term ability of the ruling class to contribute to economic development and retain its political power depends on 
its restricting the numbers in its class relative to change in the amount of its appropriated economic surplus.

Given the relationship just described, it is important to consider the mechanisms which were able to restrain increases in the membership of the ruling class. Possibly, in most cases, this cannot be ascribed to the low fertility of the rulers compared to the bulk of the population. Skirbekk (2008), for instance, points out that in several ancient societies, social status determined the number of (surviving) children fathered. Several ancient rulers had many surviving offspring because they had multiple wives or access to lots of sexual partners. However, only a few members of the ruling class may have achieved these high fertility rates and many of their offspring (for example, those born out of wedlock) may not have been permitted to become members of the ruling class. In some societies, the bureaucratic members of the ruling class (often priests) were socially restricted in their ability to bear legitimate offspring. Thus, the fecundity of a few rulers does not negate the possibility that the rate of growth in the membership of the ruling class was constrained in several early pro-development agrarian societies. Several social mechanisms made this possible.

The social classification of offspring of the ruling class as legitimate and illegitimate was one mechanism for limiting the size of this class. It is even possible that access to several sexual partners by the rulers reduced the number of their legitimate children and therefore the numbers of legitimate children able to potentially join the dominant class. Furthermore, only a selection of legitimate offspring may have had a chance to join the ruling class and the remainder might have experienced downward social mobility (Clark, 2007, p. 7). Primogeniture rules (as well as other restrictions on those able to inherit) and the exclusion of female offspring from any substantial inheritance are some of the ways in which downward social mobility was achieved. Forced migration of some members of the group was another method.

An additional mechanism for limiting the size of the dominant class was the death of members by violence. This includes homicide by members of this class, as well as death as a result of war. Clark (2007, p. 122) quotes evidence from Hollingsworth (1965) that for a substantial period of time prior to 1730, English aristocrats either did not replace their numbers or barely did so due to violence, mainly occasioned by warfare.

In many cases, the ruling class in ancient societies may have been aware that it needed to maintain (or increase) the level of its discretionary economic surplus in order to retain its dominance within its own society and fend off challenges from possible invaders and usurpers. Hence the support of the ruling class for mechanisms restricting the size of this class even if this did not include their having a low level of fertility. However, in more recent times, it is possible that reduced fertility became a major mechanism for maintaining or improving family status, even among the dominant class (Johansson, 1987; Skirbekk, 2008, p. 150). 
Conquest also sometimes reduced the numbers in the governing class, at least for some time. Following the conquest of a society by a foreign power, the conquerors mostly replaced the preexisting dominant class by their own which in many cases consisted (initially) of a smaller number than the prior ruling class. This happened, for example, several times in the case of China. In northern and central China, the Western Chou, who had been powerful in the Shaanxi province (along the upper Wei River) as the western neighbors of the Shang, defeated the Shang and dominated the region from 1122 to $771 \mathrm{BC}$. In the Common Era, for example, Kublai Khan following the successful invasion of China by the Mongols established the Yuan Dynasty (1279-1368) with his Mongol followers as the ruling class in China. Similarly, the invading Manchus established the Qing Dynasty in China (1644-1912).

It was not only by invaders that the size of the ruling class could be reduced from time to time. There were also other means, including internal rebellion. Gascoigne (2004), in relation to China, provides examples of this. These examples include peasant revolts (Gascoigne, 2004, p. 70). He also points out that these revolts often enabled some members of the elite to overthrow the top echelons of the ruling class. This happened on several occasions during the period of the Han Dynasty (206 BC-AD 220) in China. On one occasion, the generals charged with putting an end to a peasant rebellion took advantage of the situation to establish themselves as the rulers (Gascoigne, 2004, p. 72).

\section{DISCUSSION OF THE ABOVE DEVELOPMENT THEORY}

Opinions differ about whether the type of social inequality which developed after the commencement of agriculture in the Neolithic period, and which continued (with variations) until after the Industrial Revolution, retarded or promoted economic development. Galor (2005) argues that such inequality was unfavorable to economic development. However, that view depends on how one judges the presence or absence of development. If it is judged by increases in the per capita income of the bulk of the population and the extent of their freedom, one could conclude that no development occurred. However, if one considers the extent of advances in knowledge, improvements in production technologies, in the organization of societies, the extension of economic exchange, and the provision of infrastructure during this long preindustrial period, one cannot fail but to be impressed by the amount of development of human civilization which occurred. It is doubtful whether an egalitarian system (even if it could have survived given the structural change brought about by the development of agriculture) would have been able to achieve similar results. In fact, if Malthus' theory of population dynamics held, the above theory demonstrates the impossibility of economic development. In many hunter-gatherer societies, the Malthusian theory of population growth may not have held because of 
the presence of social and practical limitations on size of families (Hassan, 1981, Chapter 9). However, these constraints disappeared in agrarian societies (Childe, 1936; Hassan, 1981, p. 227).

The above theory only shows that a potential existed for development given the type of social inequality present in many agrarian societies for several millennia. In some such societies, this economic surplus was harnessed for economic development but not in all, either by choice of the rulers and by their need to use their surplus to stave off external aggression. Furthermore, the size of the economic surplus available for development may have varied historically in agrarian preindustrial societies. With the passage of time, the social system may have become ossified and bogged down in armed conflict and burdened by superstitions and social rules of conduct, thereby retarding the scope for further progress.

Childe (1936) argues that the palace-based system in ancient Egypt, for example, at first promoted economic development but not later on. In Chapter 6 (1936), Childe describes how the priestly class and the rulers of early agrarian societies (such as that of Sumer and Egypt) promoted capital accumulation and in Chapter 7, he specifies the way in which knowledge expanded in such increasingly urbanized societies. He attributes the growth in knowledge as being primarily a response to the challenges of administering societies which had increased in their economic interdependence and in the scale of their economic activities.

In Chapter 9, however, Childe (1936) provides a rather different perspective which (to some extent) is at odds with his exposition in Chapter 7. He claims that in the two millennia preceding $3000 \mathrm{BC}$, many important discoveries were made (in the often claimed cradle of Western civilization in West Asia and the Mediterranean region) which contributed to human advancement, but from about 2600 to $600 \mathrm{BC}$, "few contributions of comparable importance for human progress were made".

The urban revolution (which evolved in those parts of the globe where suitable developments in agriculture occurred and which, as pointed out by Childe (1950), was facilitated by complementary circumstances) amplified class division in agrarian economies. Somewhat contrary to his position outlined in Chapter 6, Childe argues in Chapter 9 that this increased class division retarded economic progress (Childe, 1936). He claims that the bulk of productive inventions prior to the urban revolution was made by actual producers. After the urban revolution, actual producers were relegated to the dominated class, and they could not escape from the lower class by technical improvement 'that the ruling class could hardly appreciate'. Their best hope was to join the middle class in supporting 'the established church' (Childe, 1936, p. 231). This was a recipe for the retardation of the progress of mankind. $\mathrm{He}$ concludes: 'Thus, from the point of view of progress, Egyptian and Babylonian societies were involved by the urban revolution in a hopeless contradiction. And they bequeathed the contradiction to various successor states-Hittites, Assyrians, Persians, Macedonians — that took them as models' (Childe, 1936, p. 231). 
One is left with a quandary. Is the positive view given in Chapter 6 of Childe (1936) about the role of the urban revolution in fostering development more accurate than his negative version in Chapter 9 of the consequences of this revolution for human progress ${ }^{5}$ Adding to this confusion, Childe (1950) provides an insightful analysis of the conditions required for the development of urban centers and portrays their positive contributions to development. In any case, it is not true that all societies showed lack of economic development following their increased urbanization. For example, early Chinese societies continued to develop even though before the end of the Qing Dynasty, signs of economic stagnation were apparent. Furthermore, in the West, the administrative structures of states experienced substantial change. Many states disintegrated into localized fiefdoms. In Europe, this disintegration was prevalent in the Medieval period and much of Europe's infrastructure (such as roads and bridges) fell into a serious state of disrepair (Bloch, 1962, Chapter 4). Strong divisive forces developed which retarded economic progress. Nevertheless, not all accumulated knowledge and wealth was lost in this period, and the economic functions of the urban-based middle class expanded (Bloch, 1962, Chapter 4) and eventually would provide a springboard for the commencement of the Industrial Revolution.

\section{THE PIVOTAL ROLE IN SOCIOECONOMIC DEVELOPMENT OF THE EVOLUTION OF URBAN CENTERS: ILLUSTRATIONS AND ANALYSIS}

Although very few hunter-gatherer communities were sedentary, the evolution of agriculture required virtually all agriculturally based societies to become sedentary (Hassan, 1981). Depending on the nature of agricultural production, this resulted in the emergence of urban centers of a substantial size, for example, in the Middle East. For instance, in the early Dynastic period, Uruk became a major city with 30,000-40,000 inhabitants (Hassan, 1981, p. 237). Larger urban centers were associated with the occurrence of highly socially stratified societies and played a central role in the social and economic development of their communities. The ruling class generally resided in these centers and appropriated the agricultural surplus which they then redistributed according to their wishes. This resulted in centralized management of their associated economies and restricted the population growth of the masses. This restriction was largely absent in the early stages of agricultural development when agriculturalists resided in small dispersed villages or hamlets. Apart from this consequence, growing urbanization facilitated large-scale

\footnotetext{
${ }^{5}$ Because Childe was a committed Marxist (Faulkener, 2007), he was probably reluctant to accept the possibility that economic inequality based on the exploitation of the masses could be associated with the development of civilization. This may explain the discrepancy in his conclusions.
} 
investments, the advance of knowledge (for instance, via the development of writing and mathematics), the expansion of trade and communications, and the emergence of forms of socio-political organization able to support the social cohesiveness of states and their sustainability. Large urban cities became the managerial centers of many ancient economies. It is therefore necessary to consider their role in economic development in some detail.

As indicated above, the appropriation of the agricultural surplus by a ruling elite needs to be extended by relating it specifically to the development of urban centers (cities). The mere fact that agriculture eventually was able to yield a food surplus did not in itself support the development of civilizations. However, in some parts of the world, this surplus was able to support the evolution of cities and these became an important catalyst for economic growth. It was necessary for the ruling elite (in order to strengthen its power) to be able to marshal this surplus and transport it to central places, namely cities (Smith, 2003). This required the surplus to be sizeable in total, easily transportable, and storable. Grains (such as wheat, rice, millet, maize, and the seeds of some legumes) were suited to this purpose. It is therefore not surprising that early civilizations with important cities developed in areas where these commodities were available, for example, were in Mesopotamia, Egypt, China, India, and parts of the Americas. Such commodities were able to support cities and provided the dominant class with a surplus which it could allocate to various uses, such as capital accumulation, defense and the waging of war, its own consumption, and knowledge accumulation and transmission.

The scope which early societies had for benefitting from agriculture depended significantly on their available initial resource endowments, for example, the availability of wild species suitable for domestication, their climatic conditions, the scope for navigation, and the ease of transport of produce (Diamond, 1997, Chapter 5). Localities close to the sea or rivers were at an advantage in early times because it was usually least costly and quicker to transport produce by boat than by land.

Even when agriculture developed in very early times, this did not always result in the development of cities nor significant social stratification. For example, it is believed that agriculture developed in New Guinea around 7000 BCE (Renfrew, 2007, p. 210) but no major cities developed there and Melanesian societies appear not to have become socially stratified. This could be due to a combination of factors. Agriculture in New Guinea did not produce grains but mostly tubers and bananas (plantains) both of which are more perishable than grains. Transport (because of the terrain) was also an obstacle and probably the food surplus produced by each household was not large. This situation was not favorable to the development of the type of stratified societies containing cities which developed in Eurasia, North Africa, and parts of the Americas.

In prehistory and early history, it is likely that both resource endowments and institutions were important for development but to some extent because resource 
endowments influenced the nature of agricultural commodities produced; this determined the nature of the social institutions which evolved, for example, whether or not a society was socially stratified. In recent times, many economists for example, following North (1990) and North and Thomas (1976), have portrayed institutional structures as being of greater importance as an influence on economic development than resource endowments. In fact, the influential economists D. Acemoglu and J. Robinson state that:

Political and economic institutions, which are ultimately the choice of society, can be inclusive and encourage economic growth. Or they can be extractive and become impediments to economic growth. Nations fail when they have extractive economic institutions supported by extractive political institutions that impede and even block economic growth (Acemoglu \& Robinson, 2012, p. 97).

While this statement might be correct, one ought to be skeptical about it. First, it is not clear how much choice societies have about their institutions. To a considerable extent, they may be socially embedded and subject to evolutionary forces over which individual societies have little control (Gowdy \& Krall, 2014). Secondly, historical evidence also indicates that nations do not always fail quickly when they have extractive economic and political institutions. For example, the Sumerian civilization lasted for more than 1,500 years, that of ancient Egypt for over 2,000 years and arguably, that of China also for over two millennia, and many other early civilizations including that of the Romans, those of the Mayans, and the Incas lasted for several hundreds of years (Haywood, 2010). Whether or not any of today's nations having more inclusive societies will last for several millennia is not at all clear.

Urban centers (cities) played a major role in the development of preindustrial societies which relied on extractive institutions for their development. Cities were crucial in the development process because they allowed wealth and power to be amassed and they enabled the rapid exchange of ideas among relatively large numbers of people, thereby encouraging intellectual thought and artistic expression. Cities also promoted specialization in manufacturing and trade and fostered the emergence of centers of political power (Baker, Bulte, \& Weisdorf, 2010). In cities, as settlements grew so large that not everyone knew each other, residents could no longer rely on family and village leaders to settle disputes or to decide issues for the whole community. Large societies therefore developed governments, often starting with a single strong leader who, as the need arose, empowered others to assist him. Over time, the result was the introduction of a government and its associated administration, that is an array of officials who carried out decisions, maintained order, organized food reserves, supervised construction projects, and resolved conflicts among strangers. A government's main functions were to secure the society's sustenance, ensure the survival of its ruling elite, and defend against outsiders. The 
connection between Bronze Age urbanization and the political development of states and emergence of ruling elites is supported by considerable evidence. Urbanization is connected with the development of new crafts and craft skills (for example, metallurgy), that is with specialization, and also with institutions that coordinated multiple production activities and infrastructure. This is why, since Childe (1936), scholars have used the term 'Urban Revolution' for this transformation.

\subsection{Urbanization, Labor Specialization, and Coordination}

Even in ancient societies, urbanization changed the nature and the consequences of settlement. The city is not just a denser and larger settlement than the rural villages that support it with food and fuel. It is also a social entity where people are linked together not by the ties of kinship as in tribal society, but by their interdependence and functional complementarity. Although towns and cities depended on farming, their most influential inhabitants were those who did not farm (Wailes, 1996). With their food supplied by farmers, these people could specialize in other occupations. Indeed, city life and clustering makes sense only when there are several persons engaged in diverse non-food producing occupations such as metallurgy, stone carving, administration, serving the temples, and trade. Producers of non-subsistence goods were largely dependents of the rulers or temples. The more specialization there was, the more individuals depended on supra-household organization mechanisms and less on face-to-face community ties. Instead of being a total of so many tribes and clans, the city was a population held together by regulation and coordination. The elite ensured not only law and order, but the administrative structure for organizing the division of labor. The ruling elite demanded the labor of the urban populace, if not token tribute as well. Overarching administrative and regulatory structures such as this ran on systems of recording (writing) and calendar keeping. This is why there is a logical connection between the coming of cities and the existence of states or societies ruled by elites.

\subsection{Metallurgy}

The development of metallurgy marks a shift from simple to advanced agrarian societies and highlights the role of the elite in economic development. Metallurgy appeared during the Neolithic period, and the Bronze Age represents a true leap forward in technology of metal work and therefore of other crafts using metal tools. Most important is a point emphasized by Gordon Childe: these items were produced for the urban elite rather than the populace. Metallurgy came into its own when specialists produced objects for royal ancestor rituals as in China, or tools for urban workshops of the Mesopotamian temple and palace establishments, or for mortuary cults as in Egypt. Not only were such institutions a source of sustained demand, but 
the infrastructure, such as fuel, raw material, and the day-to-day needs of metallurgists, could be provided. The social context of such technological development was the emerging division of labor and specialization, and also demand from ruling elites and their productive establishments. Hence, the implications of metallurgy were fully realized only with the coming of states and/or cities.

\subsection{Infrastructure}

Urbanism is possible only when the land has a capacity to support a large number of people per unit area: because it entails the clustering of people in dense settlements, rather than their relatively even dispersal across the landscape. Also necessary are technologies that make feasible the transport of bulky food grain to the non-farming populations of urban nodes. In ancient history, infrastructure consisted mainly of roads (Lay, 1992) and canals. The latter were used for transportation or for irrigation (Rodda \& Ubertini, 2004). The first paved streets appear to have been built in Ur in 4000 BC. In 500 BCE, Darius I the Great started an extensive road system in Persia while, as it is well known, Romans built an extensive road system with the rise of the Roman Empire.

It has long been noted that early cities and states all arose in river valleys in semiarid regions. ${ }^{6}$ Thus, it can be held that such environments prompted the formation of states since the latter were probably created to organize vast numbers of people to build banks and dikes for flood control and irrigation systems to bring river water to farm fields. The oldest known canals were built in Mesopotamia $4000 \mathrm{BC}$. In Egypt, canals date back to at least $2300 \mathrm{BC}$, when a canal was built to bypass the cataract on the Nile near Aswan. In ancient China, large canals for river transport were established as far back as the Warring States (481-221 BC). By far, the longest canal was the grand canal of China completed in $609 \mathrm{CE}$, and is still the longest canal in the world today at $1,794 \mathrm{~km}$.

A few advanced cities had aqueducts that serviced public fountains and baths. There is also the evidence that Harappan urban centers provided a street drainage system and other civic infrastructures. Street drainage functions only as a planned whole. Individual households cannot organize it piecemeal and therefore this system appears to have been the outcome of regulation and coordination by the elite.

\subsection{Trade}

There is a marked correlation between the period of state emergence and an expansion of trade in Egypt, Sumer, and South Asia. This trade expansion is, to a large

\footnotetext{
${ }^{6}$ In the fourth and third millennia BC, early cities, states, and civilizations arose near rivers in Egypt, Mesopotamia, the Indus Valley, and China. One of the advantages of this was the facilitation of the transport of goods.
} 
extent, explained by activity undertaken by the elite. In addition to special privileges over land, water sources, mines, or pastures, the members of the elite often assumed a sacral role, distinguishing themselves from the rest of the populace by ostentatious consumption (of metal work, exotic stone beads, shell carvings, etc.) and feigned mysterious powers. Thus, there were imperatives to organize the imports of high status cum utilitarian things. It also appears that the procurement of metals and semiprecious stones from afar for the elite created a need for ever larger quantities of these. During the Bronze Age and from the elite's point of view, the development of centers of civilization generated in them the need to acquire their own bronze weaponry to defend themselves or to organize the mass casting of weapons for military expeditions and conquests. We may probably claim that the more successful a ruler was in procuring copper and its alloying metals, the more military success he would have. Therefore, economies utilizing bronze tools of production and bronze weapons were highly dependent on elite organization of external trade (especially to obtain tin which was very scarce) and local production.

Nevertheless, it should not be concluded that trade in preindustrial societies was only for the purpose of providing prestige products for the ruling class and metals for war and defense (Chapman, 2008). For example, the economy of the Inca Empire (1000-1533 CE) relied on trade between different climatic zones of the Andes to stabilize its food supplies and its rulers built an extensive road system to facilitate this trade. They also developed irrigation in some of its arid areas. According to Haywood (2010, p.211), 'the products of the different environmental zones were exchanged vertically between communities' and this 'provided considerable insurance against the failure of any individual crop'. The Inca rulers also constructed large storehouses of food to be drawn on in times of need.

In the Old World, it is possible that with the development of the Iron Age, the ruling elites concentrated more on waging war to fill their coffers and less on increasing domestic production and expanding peaceful external trade to extract a greater amount of economic surplus. To an increasing extent, they lived off their subject populations, acquiring booty, enslaved labor, captive artisans, and relied on regular flows of tribute. This undoubtedly retarded economic development.

\subsection{Defense and Conquest}

By 7000 BCE, as food supplies increased, some West Asian settlements grew quite large. Jericho in Palestine and Çatal Hüyük in what is now Turkey, for example, developed into towns, that is large settlements, housing several thousand people that served not only as residential centers but also as trading hubs. By the fourth millennium BCE, near the Tigris and Euphrates rivers in West Asia and the Nile in northeast Africa, some towns grew into cities. These were very large, complex, densely populated settlements in which many people engaged in occupations other 
than farming. At these sites, excavations reflect the emergence of organized religion and give the impression that rulers exercised great power. Fortifications and weapons found in early cities suggest that they must have had numerous laborers to build the walls and watchtowers, soldiers to defend against outsiders, and governing officials with the authority to organize and supervise large groups of workers and warriors (Gat, 2006, pp. 167-173).

From around 1800 BCE onwards, a new type of state, which may loosely be referred to as an empire, began to emerge, initially in West Asia. ${ }^{7}$ As a type of state, the empire encompassed a fairly large territory which was not confined to a given geographical zone. It was usually, though not always, monarchical, had extensive military resources, and relied on the collection of a large amount of tribute. Every empire had a core area as its political center, and the ruling class of the empire belonged overwhelmingly to this core area. It was through conquest that the ruling elite of an area could establish its domination over other areas. The sheer logic of empire building necessitated the mobilization of a large well-trained army and resources to sustain such an army. Thus, empire building, appropriation of large surpluses in the form of tribute, and maintaining huge armies were all closely interlinked.

\subsection{Knowledge Accumulation and Transmission}

Knowledge is partly conceived of as the increasing capacity of an individual, a group, or a society to solve problems and to mentally anticipate the necessary actions to do this. In early societies, knowledge was particularly tied to the management of the economy. Hyman and Renn point out:

\footnotetext{
Sociocultural evolution inherently involves knowledge that is efficacious, either with respect to the physical world or with respect to the social world. [...] this knowledge economy was almost completely tied to the underlying economy of labour. For example, literacy was closely correlated with socioeconomic status, and in Babylonia astronomical knowledge was pursued for agricultural and legitimatory ends, so that the pursuit of astronomical knowledge was ultimately motivated by economic concerns (Hyman \& Renn, 2012, p. 95).
}

In most ancient societies, a priestly class (supported by the elite) was often mainly responsible for the advancement of knowledge. Beyond the creation of knowledge, it is also necessary to consider knowledge as something that may be shared by members of a profession, a social class, a geographic region, or even an entire civilization. Shared knowledge is especially important to the artistic, religious, legal, and economic systems that constitute cultures; and knowledge travels along with

\footnotetext{
${ }^{7}$ Initially, the Babylonian state in Mesopotamia and, somewhat later, the Hittite state in Anatolia were successful at bringing large territories under their control.
} 
artifacts and artistic styles, myths and rituals, laws and norms, goods and wealth. This distribution is facilitated by external representations of knowledge such as spoken language, writing, and technological artifacts. Spoken language ${ }^{8}$ has always constituted one of the chief means of transmitting knowledge, and language spreads with migration, conquest, and trade.

However, the invention of writing ${ }^{9}$ created a new and powerful tool for the transmission of knowledge since it enabled knowledge to travel, in both time and space, beyond the immediacy of the speech situation. The invention of writing in Mesopotamia was originally a consequence of state administration. With writing came metrologies, calculation techniques, and finally the rise of the first sciences. Trade and the exchange of goods on a larger scale were also developed, accompanied by written contracts, agreements, and systematic and regulated forms of communication also developing into multilingual formats. Mathematics emerged in ancient Babylonia when the material means of organizing human labor, such as accounting systems, became an object of intellectual exploration.

Religion was one of the most important conveyors of the globalization of knowledge and of science in the period between antiquity and the early modern era. It has often been argued that knowledge travelled with rituals (and associated verbal recitations); specific geometrical knowledge needed to construct ritual altars was transmitted. It is also true that in many agrarian societies, impressive temples, shrines, and mausoleums were built. While these might not have been productive, they played an important part in the social cohesion of these early societies and their construction would have helped advance building skills.

The accumulation and transmission of knowledge were largely contingent on the emergence of a social network that supported the production and dissemination of knowledge. Hubs in this network were typically flourishing trade or religious centers, or capital cities of large empires. Empires further facilitated the wide range diffusion of knowledge and, in particular, the integration of knowledge emerging from different hubs.

\subsection{Observations from the Above}

In preindustrial societies where agriculture developed and had attributes enabling it to support the growth of cities, this increased the power of the dominant class, if such a class already existed. If it did not exist, it enabled it to emerge and become powerful. Cities facilitated the ability of this class to accumulate wealth by appropriating the agricultural surplus and as demonstrated, cities played (by varied means) an important role in adding to wealth and fostering development. Despite Childe's

\footnotetext{
${ }^{8}$ Before $3000 \mathrm{BC}$, speakers of a Proto-Indo European language began to spread throughout Eurasia.

${ }^{9}$ Writing appeared around $3300 \mathrm{BC}$ in Mesopotamia; the largest group of texts is from Uruk.
} 
(1936) ambivalence about the role of cities in development, socioeconomic development would have been much slower in the absence of cities. Even though ancient agrarian societies were extractive and non-inclusive, many lasted for hundreds of years (some for over a millennium) and did add to wealth, a result which seems to be at variance with the prediction of Acemoglu and Robinson (2012, p. 97) that such societies are likely to fail quickly.

It is also relevant to note that there is some evidence of population increase being more rapid in early agricultural communities than following the development of significant urban centers. Carneiro and Hilse (1966) estimated that population growth in the Near East averaged about $0.1 \%$ p.a. from the beginning of the Neolithic to about 4000 BC. Moreover, Hassan and Sengel (1973) estimated a similar figure for early farming communities in various parts of the world. Butzer (1976) calculated that the growth rate of population in Pharaonic Egypt averaged 0.05\% per year for the period from 3000 to $150 \mathrm{BC}$. This is consistent with the possibility that the development of urban centers and the extraction of the agricultural surplus restrained population growth in some agriculturally based societies. However, this is not the only possible explanation of this phenomenon.

\section{CONCLUDING COMMENTS}

Many ancient agrarian societies faced an economic and social dilemma. If they became egalitarian, the increased economic surplus made possible by the development of agriculture and urban settlements would have been frittered away by population increases and would have resulted in all living at subsistence level. Furthermore, in such circumstances, an insufficient surplus would have been available for defense purposes. In these circumstances, social inequality was probably a more desirable alternative to equality from a long-term development point of view.

Given the theory outlined here, a small dominant or ruling class (the membership of which was limited) was able to extract an economic surplus from the large dominated class. This limited the expansion in the size of the population of the dominated group who, however, after appropriation of the surplus, continued to live at subsistence level. The appropriation of this surplus enabled the ruling class to provide for military expenditure and to engage in capital accumulation, as well extravagant consumption. The development of their society depended on the balance achieved between these allocations of the economic surplus. Some rulers were able to contribute substantially by capital accumulation and by the advancement of knowledge to increased economic production. On the other hand, some rulers squandered the economic surplus and this resulted ultimately in the demise of their societies. 
By modern standards, such a socioeconomic system seems to be reprehensible but the alternative agrarian system involving equality would hardly have been more desirable. As pointed out by Childe (1950, p. 16), in an agrarian system dominated by a small group, 'there seemed [to be] a glaring conflict of economic interests between the tiny ruling class, who amassed the bulk of the social surplus, and the vast majority who were left with a bare subsistence and effectively excluded from the spiritual benefits of civilization'. However, in the alternative egalitarian socioeconomic system, all would have been doomed to live at subsistence level and no surplus would have been available for capital accumulation and for the advancement of knowledge.

A socioeconomic system based on agriculture and inequality existed for many millennia, and was only replaced by a different system following the Industrial Revolution. It can be argued that the success of the Industrial Revolution depended on developments which occurred in agrarian-based economies following the commencement of agriculture in the Neolithic period, although possibly the commencement of the Industrial Revolution was eventually retarded by the inequality present in preindustrial societies. The new economic system following the Industrial Revolution transformed social structures, and eventually enabled the bulk of populations in many societies to exist at standards of living well above the subsistence level. However, the long-term environmental sustainability of economic growth based on the existing economic system has become a subject of increasing concern, even though it has enabled a larger global population to exist at a higher standard of living than ever before..$^{10}$

\section{ORCID}

Serge Svizzero (D) http://orcid.org/0000-0003-3895-7273

\section{REFERENCES}

Acemoglu, D., \& Robinson, J. (2012). Why nations fail: The origins of power, prosperity and poverty. New York, NY: Crown Publishers.

Alfani, G. (2015). Economic inequality in northwestern Italy: A long-term view (fourteenth to eighteenth centuries). The Journal of Economic History, 75, 1058-1096.

Ashraf, Q., \& Galor, O. (2011). Dynamics and Stagnation in the Malthusian epoch. American Economic Review, 101, 2003-2041.

Baker, M., Bulte, E., \& Weisdorf, J. (2010). The origins of governments: From anarchy to hierarchy. Journal of Institutional Economics, 6, 215-242.

\footnotetext{
${ }^{10}$ Earlier versions of this article have been significantly improved as a result of the helpful comments of two anonymous referees. We thank them for their constructive suggestions. The usual caveat applies.
} 
Bloch, M. (1962). Feudal Society (2nd ed.). London: Routledge and Kegan Paul (Translated from the French).

Boserup, E. (1965). The conditions for agricultural growth: The economics of Agrarian change under population pressure. Chicago, IL: Aldine.

Boserup, E. (1981). Population and technological change: A study in long-term trends. Chicago, IL: University of Chicago Press.

Brenner, R. (1976). Agrarian structure and economic development in pre-industrial Europe. Past and Present, 70, 36-75.

Butzer, K. W. (1976). Early hydraulic civilization in Egypt, a study in cultural ecology. Chicago, IL: Chicago University Press.

Callender, G. (1994). The Minoans and the Mycenaeans: Aegean society in the bronze age. Oxford: Oxford University Press.

Carneiro, R. L., \& Hilse, D. F. (1966). On determining the probable rate of population growth during the Neolithic. American Anthropologist, 68, 177-181.

Chapman, J. (2008). Approaches to trade and exchange in earlier prehistory: Late Mesolithic early bronze age. In A. Jones (Ed.), Prehistoric Europe: Theory and practice (pp. 333-355). Oxford: Wiley-Blackwell.

Childe, V. G. (1936). Man makes himself (4th ed). London: Watts \& Co.

Childe, V. G. (1950). The urban revolution. Town Planning Review, 21, 3-17.

Clark, G. (2007). Farewell to alms: A brief history of the world. Princeton, NJ: Princeton University Press.

Cohen, M. N. (1977). The food crisis in prehistory: Overpopulation and the origins of agriculture. New Haven, CT: Yale University Press.

Cunliffe, B. (2015). By steppe, desert and ocean: The birth of Eurasia. Oxford: Oxford University Press.

Deevey, E. S. (1960). The human population. Scientific American, 203, 194-204.

Diamond, J. (1997). Guns, germs and steel: The fates of human societies. New York, NY: W.W. Norton.

Diamond, J. (2013). The world until yesterday. New York, NY: Viking Press.

Faulkener, N. (2007). International socialism. A Quarterly Journal of Socialist Theory, 116. Retrieved October 27, 2014, from https://www.isj.org.uk/index.php4?id=367\%20=116

Galor, O. (2005). Unified growth theory: From stagnation to growth. In P. Aghion \& S. Durlauf (Eds.), Handbook of economic growth (pp. 171-294). Amsterdam: Elsevier.

Galor, O., Moav, O., \& Vollrath, D. (2009). Inequality in landownership, the emergence of humancapital promoting institutions, and the great divergence. Review of Economic Studies, 76, 143-179.

Gascoigne, B. (2004). The dynasties of China. London: The Folio Society.

Gat, A. (2006). War and human civilization. Oxford: Oxford University Press.

Gowdy, J., \& Krall, L. (2014). Agriculture as a major evolutionary transition to human ultrasociality. Journal of Bioeconomics, 16, 179-202.

Hassan, F. A. (1981). Advances in archaeological method and theory. New York, NY and London: Academic Press.

Hassan, F. A., \& Sengel, R. A. (1973). On mechanisms of population growth during the Neolithic. Current Anthropology, 14, 535-542. 
Haywood, J. (2010). The ancient world. London: Quercus.

Hollingsworth, T. H. (1965). The demography of the British peerage. London: Population Investigation Committee, London School of Economics.

Hyman, M. D., \& Renn, J. (2012). Survey: From technology transfer to the origins of science. In J. Renn (Ed.), The globalization of knowledge in history (pp. 75-104). Open Access Edn., Berlin: Max Planck Research Library for the History and Development of Knowledge.

Johansson, S. (1987). Status anxiety and demographic contraction of privileged populations. Population and Development Review, 13, 439-470.

Kuznets, S. (1955). Economic growth and income inequality. American Economic Review, 45, $1-28$.

Lay, M. G. (1992). Ways of the world. Sydney: Primavera Press.

Lee, R. D. (1986). Malthus and Boserup: A dynamic synthesis. In D. Coleman, \& R. Schofield (Eds.), The state of population theory: Forward from Malthus (pp. 96-130). Oxford: Basil Blackwell.

Lee, C. T., Puleston, C. O., \& Tuljapurkar, S. (2009). Population and prehistory III: Food-dependent demography in variable environments. Theoretical Population Biology, 76, 179-188.

Lee, C. T., \& Tuljapurkar, S. (2008). Population and prehistory I: Food-dependent population growth in constant environments. Theoretical Population Biology, 73, 473-482.

Livi-Bacci, M. (2007). A concise history of world population. Malden, MN and Oxford: Blackwell Publishing.

Maddison, A. (2007). Contours of the world economy 1-2030 AD. Oxford: Oxford University Press.

Meek, R., Raphael, D., \& Stein, P. (Eds.). (1978). Adam Smith: Lectures on jurisprudence. Oxford: Clarendon Press.

Milanovic, B., Lindert, P. H., \& Williamson, J. G. (2007). Measuring ancient inequality (NBER Working Paper Series, Working Paper 13550). Retrieved from https://www.nber.org/papers/ w13550

Milanovic, B., Lindert, P. H., \& Williamson, J. G. (2011). Pre-industrial inequality. The Economic Journal, 121, 255-272.

North, D. C. (1990). Institutions, institutional change and economic performance. New York, NY: Cambridge University Press.

North, D. C., \& Thomas, R. P. (1976). The rise of the western world: A new economic history. London: Cambridge University Press.

Puleston, C. O., \& Tuljapurkar, S. (2008). Population and prehistory II: Space-limited human populations in constant environments. Theoretical Population Biology, 74, 147-160.

Renfrew, C. (2007). The making of the human mind. London: Weidenfeld and Nicolson.

Rodda, J. C., \& Ubertini, L. (2004). The basis of civilization - Water science? Wallingford: International Association of Hydrological Sciences Press.

Skirbekk, V. (2008). Fertility trends by social status. Demographic Research, 18, 145-180.

Smith, M. L. (Ed.). (2003). The social construction of ancient cities. Washington, DC: Smithsonian Institution Press.

Svizzero, S., \& Tisdell, C. A. (2016). Economic evolution, diversity of societies and stages of economic development: A critique of theories applied to hunters and gatherers and their successors. Cogent Economics \& Finance, 4(1), 1161322. 
Tisdell, C. A. (2005). Economics of environmental conservation (2nd ed.). Cheltenham and Northampton, MA: Edward Elgar.

Tisdell, C. A. (2013). Competition, diversity and economic performance. Cheltenham and Northampton, MA: Edward Elgar Publishing.

Wailes, B. (Ed). (1996). Craft specialization and social evolution: In memory of V. Gordon Childe. Philadelphia, PA: University Pennsylvania, Musum of Archaeology and Anthropology.

Zeder, M. A. (2009). The Neolithic macro-(r)evolution: Macroevolutionary theory and the study of culture change. Journal of Archaelogical Research, 17, 1-63. 